\title{
Erratum: Breed se bybelse pastorale model Skriftuurlik begrond in 2 Petrus 1:3-11: 'n Eksegetiese toeligting
}

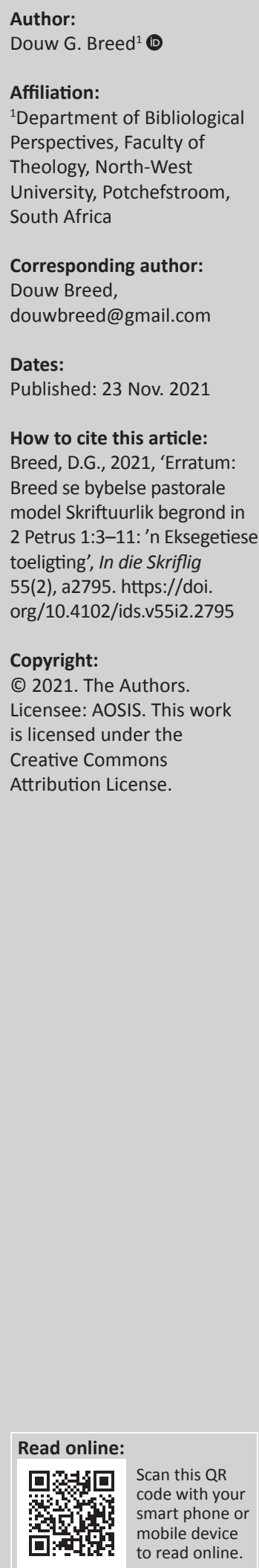

In the version of this article initially published, Breed, D.G., 2021, 'Breed se bybelse pastorale model Skriftuurlik begrond in 2 Petrus 1:3-11: 'n Eksegetiese toeligting', In die Skriflig 55(2), a2673. https://doi.org/10.4102/ids.v55i2.2673, the accepted date was given incorrectly. The correct acceptance date should be 21 Oct. 2020 instead of 21 Oct. 2021.

This correction does not alter the study's findings of significance or overall interpretation of the study results. The publisher for any inconvenience caused. 


\section{Breed se bybelse pastorale model Skriftuurlik begrond in 2 Petrus 1:3-11: 'n Eksegetiese toeligting}

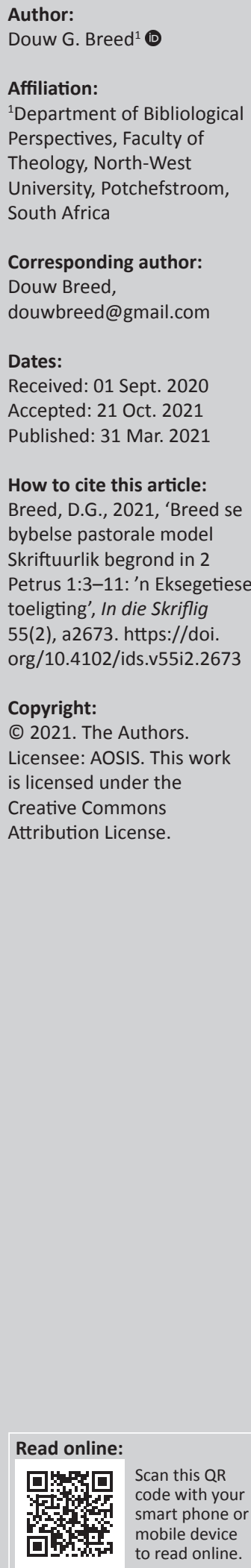

Breed's biblical pastoral model Scripturally grounded in 2 Peter 1:3-11: An exegetical elucidation: In his recent research, Gert Breed has formulated a biblical pastoral model. From his own publications as well as from publications of other researchers, it is clear that Breed's model is of great value to pastoral counsellors. Although elements of the model are included in other people's research publications, Breed has not yet published a complete description of his model. The purpose of this article is to provide Breed's pastoral model with a biblical foundation from 2 Peter 1:3-11 within the context of the entire letter. The method used in this study was to do exegesis of 2 Peter 1:3-11 according to the grammatical-historical model, and to use the results of the exegesis to biblically ground the different elements of Breed's pastoral model. The article found that seven important elements of Breed's model can be Scripturally grounded in 2 Peter 1:3-11, namely: (1) the meta-theoretical starting point regarding the Bible as the Word of God; (2) the need for someone receiving counselling to be born again; (3) the importance of a counselee's relationship with God; (4) change in the life of a counselee through insight; (5) external and internal motivation of a counselee; (6) perseverance in a new life; and (7) the counselee as diakonos of Jesus Christ. Breed's pastoral model is already useful for pastoral counsellors. The exegetical grounding presented in this study increases the usefulness of the model.

Contribution: This article makes a contribution to the usefulness of Breed's pastoral model by providing it, on the basis of exegesis, with a closer biblical foundation.

Keywords: Peter 1:3-11; Pastoral model; biblical foundation; born again; perseverance; insight; motivation; Diakonos.

\section{Inleiding}

Gert Breed ${ }^{1}$ het in sy navorsing die afgelope agt jaar in die besonder aan 'n bybels-pastorale model aandag gegee. Hoewel G. Breed nog nie 'n volledige beskrywing van die model gepubliseer het nie, is die belangrikste elemente van die model duidelik uit van sy publikasies asook uit sy PAST122-lesings. Ek kon ook 'n persoonlike onderhoud met G. Breed voer om tot beter begrip van die model te kom.

Dit blyk dat die bybels-pastorale model tot groot hulp vir beraders is. Uit publikasies van G. Breed (2017) is dit duidelik dat dit bruikbaar is in die berading van gelowiges wat aan pornografie verslaaf is sowel as gelowiges met 'n narsistiese persoonlikheidsteuring (Breed 2019b:1-19). Pretorius (2017:194-213) het G. Breed se model gebruik as 'n raamwerk vir 'n prakties teologiese model vir die pastorale sorg en berading van die gesinne met dowe kinders. Nickols (2019:139-151) het die model aangepas om emosioneel-verwonde kinders te beraad. Sy sê ook dat die model geskik is om in verskillende pastorale omstandighede te gebruik soos huweliks-, trauma- en verslawingsberading. In die lig van Pretorius en Nickols se studies is in hierdie artikel aanvaar dat G. Breed se model wetenskaplik begrond is en deur beraders effektief gebruik kan word.

Hoewel hierdie artikel die pastorale model van G. Breed aan die orde stel, is dit nie 'n pastorale ondersoek nie en word daar ook nie gepoog om die model eksegeties of volgens pastorale doelwitte te beoordeel nie. G. Breed se model word ook nie met ander pastorale modelle vergelyk nie. Hierdie artikel poog om tot die bruikbaarheid van die model by te dra, deur op 'n eksegetieswetenskaplike wyse verdere bybelse begronding uit 2 Petrus aan die model te bied. Daar word in hierdie artikel gekonsentreer op die bybelse begronding wat 2 Petrus 1:3-11 binne die konteks van die hele brief bied.

1.Twee persone met dieselfde van, naamlik Douw en Gert Breed word in die artikel deur hulle voorletters onderskei. 
In hierdie artikel word eerstens 'n kort opsomming van G. Breed se model gegee. Tweedens word ondersoek ingestel of dit verantwoordbaar is dat 2 Petrus in die konteks van pastorale sorg as begronding gebruik word. Vervolgens word spesifieke elemente van hierdie model aan hierdie orde gestel en word nagegaan of 2 Petrus 1:3-11 as begronding van die elemente kan dien.

In die eksegese wat in hierdie artikel aangebied word, word die grammaties-historiese model gevolg soos dit binne die gereformeerde tradisie beoefen is (Breed \& Van Staden 2015:563-566; Fee 2009:29-132; Jordaan, Janse van Rensburg \&Breed 2011:225-258). Dieontleding van diegedagtestruktuur is in die artikel gedoen volgens die metode wat deur Coetzee (1988:19-37; vgl. ook Cotterell \& Turner 1989:230-256) ontwikkel en deur Breed (1994:45-77) nader uitgewerk is (Breed \& Janse van Rensburg 2001:411). Vir die bepaling van die betekenisse waarvoor Griekse woorde in 2 Petrus gebruik word, is die metode van komponensiële analise gebruik (vgl. Louw \& Nida 1988:vi-xx).

\section{'n Opsomming van G. Breed se pastorale model}

Volgens G. Breed se model, verloop die berading van 'n persoon in vier fases. In die eerste fase val die klem op die bou van'n vertrouensverhouding tussen die berader en die persoon wat beraad word. ${ }^{2}$ In hierdie fase gee die berader en die beradene voorlopig saam aandag aan byvoorbeeld die beradene se oortuigings, vrese en verlangens. In die tweede fase word die beradene in die teenwoordigheid van God gebring (coram Deo) en bepaal die berader saam met die beradene wat die betekenis van God se openbaring vir die beradene se probleem is. Derdens volg ' $n$ fase waar daar by die beradene ' $n$ nuwe wyse van dink en doen vasgelê word en word hy of sy ondersteun om as Christus se diakonos ${ }^{3}$ te leef. In die vierde fase val die klem op die hulp en ondersteuning van ander gelowiges aan die beradene om in sy of haar nuwe lewe te volhard. Die berader tree in hierdie fase op die agtergrond (Breed 2019a:[4, 7, 9]; 2019b:5; Nickols 2019:139-140; Pretorius 2017:206-212). Die fases van die model word op'n geïntegreerde wyse bespreek ${ }^{5}$ wanneer gehandel word oor die begronding van die onderskeie elemente van G. Breed se model.

\section{Skriftuurlike begronding van 'n bybels-pastorale model in 2 Petrus 1:3-11}

Wanneer skrywers oor die aard van 2 Petrus handel, word meestal aandag gegee aan die vraag of die geskrif ' $n$ ware

2.Daar word voortaan na beradene (meervoud: beradenes) verwys wanneer die persoon wat beraad word, ter sprake is.

3.Verderaan in die artikel word duidelik gemaak waarna G. Breed met die woord diakonos verwys.

4.Die getal(le) in vierkantige hakies verwys telkens na spesifieke lesings van PAST122 wat G. Breed in 2019 aangebied het.

5.Dit is uit Pretorius (2017:193) se studie duidelik dat G. Breed in sy pastorale mode elemente en beginsels van verskeie skrywers soos Larry Crabb, Tim LaHay, John McArthur, Graig Groome, William Backus, Paul Trip en Richard Osmer geïnkorporeer het. brief is (Green 2008:162-170); of dit tot die testamentgenre behoort (Charles 1997:49-75; Donelson 2010:213); of die geskrif ooreenkom met die vaste homiletiese patroon wat in Joodse en vroeg-Christelike literatuur gebruik is (Bauckham 1983:174) en of die skrywer die geskrif in die vorm van 'n Hellenisties koninklike en siviele dekreet gestruktureer het (Danker 1978:64-82; Green 2008:179). Die moontlikheid dat die brief pastoraal van aard is, ontvang nie werklik enige indringende aandag nie.

In die brief is ' $n$ hele aantal opsigtelike sake wat die pastorale aard van die brief aandui. Dit is veral in die twee gedeeltes, 2 Petrus $^{6}$ 1:12-15 en 3:1-2, waar Petrus ${ }^{7}$ die doel van sy skrywe aandui (Breed \& Janse van Rensburg 2001:412) waarin die pastorale aard van die skrywe sigbaar word. Die skrywer verklaar duidelik sy omgee vir die lesers en sy wil om hulle te begelei. Hy wil hulle aanhou herinner, al weet hulle sekere dinge reeds (1:12). Hy skryf dat hy hulle wil opskerp terwyl hy nog leef (1:13-14). Hy wil hê dat hulle, nadat hy reeds dood is, steeds die dinge waaraan hy hulle herinner het tot hulle beskikking sal hê (1:15). Ook in 3:2 maak hy dit duidelik dat hy die lesers tot helder denke wil opskerp.

Die pastorale aard van die brief blyk ook uit die feit dat die lesers se standvastigheid in die geloof vir die skrywer van groot belang is. Hy noem dat die lesers standvastig ( $\left.\sigma \tau \eta \tilde{i}_{\zeta} \omega\right)$ is in die waarheid (1:12); dat vals leraars daarop gerig is om mense wat nie standvastig is nie ( $\dot{\alpha} \sigma \tau \eta \dot{\rho} \rho \iota \tau \varsigma \varsigma)$ te verlei (2:14);

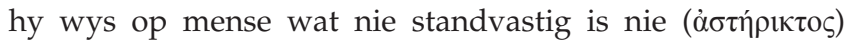
en wat die briewe van Paulus verdraai (3:16); en dit is vir hom van groot erns dat die lesers nie hulle standvastigheid ( $\sigma \tau \eta \iota \gamma \mu o ́ \varsigma)$ sal verloor nie (3:17).

2 Petrus 1:3-11 neem 'n sentrale plek in die brief in. In dié gedeelte gee Petrus 'n opsomming van sy leer en verdedig hierdie leer in die res van die geskrif (Bauckham 1983:193). Hierdie gedeelte (1:3-11) is een van die nege groter gedagteeenhede van die brief. Die gedagte-eenhede kan soos volg uiteengesit word: aanhef (1:1-2); opsomming van die leer van die apostel (1:3-11); doel van die skrywe (1:12-15); fundering van die gesag van die apostel (1:16-21); waarskuwing teen die vals leraars (2:1-22); doel van die skrywe (3:1-2); sekerheid van die koms van die Here (3:4-16); slot van die brief (3:17-18a); en lofprysing (3:18b; Breed 1994:45-84).

Dit kan aanvaar word dat dit vanweë die pastorale aard van 2 Petrus moontlik is dat daar in die geskrif en in die besonder die gedeelte waarin die apostel Petrus sy leer opsom (1:3-11), begronding vir 'n bybels-pastorale model gevind sou kon word.

6.Voortaan sal alle verwysings na 2 Petrus slegs met hoofstuk- en versnommers aangedui word.

7. Hoewel baie skrywers soos Vinsons, Wilson en Mills (2010:261-267), Watson en Callan (2012:137-139) en Butticaz (2016:341-363) dit betwyfel dat 2 Petrus deur die apostel Petrus geskryf is, toon Breed (1994:11-26), Kruger (1999:645-671) die apostel Petrus geskryf is, toon Breed (1994:11-26), Kruger (1999:645-671),
Schreiner (2003:255-282) en Van Houwelingen (2010:119-129) oortuigend aan dat daar goeie gronde is om te aanvaar dat dit wel deur die apostel geskryf is. 


\section{Begronding van die onderskeie elemente van G. Breed se model Die metateoretiese vertrekpunt aangaande die Bybel as die Woord van God}

Breed (2013:5-6) stel as metateoretiese vertrekpunt dat die Bybel as die Woord van $\mathrm{God}^{8}$ die primêre bron van studie in die pastorale wetenskap behoort te wees. Sowel die gerigtheid as die inhoud van die pastorale gesprek moet deur die Woord bepaal word. Vir hom gaan die rykdom van die bybelse leer oor die deel-hê aan die verlossing in Jesus Christus en 'n lewe van oorwinning deur die kragtige werking van die Gees (Breed 2019a:[1-4]; 2019b:9).

Dat die Woord van God die gerigtheid en die inhoud van berading in G. Breed se pastorale model bepaal, word duidelik uit die fases van die model. Soos reeds genoem, staan die bou van 'n vertrouensverhouding tussen die berader en die beradene in die eerste fase voorop. In hierdie fase is Osmer (2008) se 'descriptive-empirical task' en die vraag 'What is going on?' asook Osmer se 'interpretive task' met die vraag 'Why is it going on?' aan die orde (Breed 2019a:[2, 7]). Die berader moet in hierdie fase poog om met die Skrif as maatstaf voorlopig te verstaan op watter leuens die beradene sy of haar lewe bou en met watter waarhede uit die Skrif die beradene hierdie leuens behoort te vervang (Breed 2019a:[1, 9]).

In die tweede fase staan die Bybel as die Woord van God sentraal wanneer die beradene coram Deo gelei word. Onder leiding van die berader moet die beradene tot die besef gebring word wat die betekenis van die Godsopenbaring vir die probleem is waarmee hy of sy worstel. Die berader toets in hierdie fase sy of haar voorlopige waarneming, ten opsigte van die onwaarhede waarop die beradene se oortuigings gebou is, aan die beradene se eie insigte. Hulle ontdek dan saam uit die Woord die waarhede waarmee alle vals oortuigings vervang moet word. In hierdie fase is Osmer se 'normative task' met die vraag 'What ought to be going on?' en die 'pragmatic task' met die vraag 'How might we respond?' aan die orde. Dit is belangrik dat die beradene in hierdie fase oortuig raak van die leuens wat hy of sy geglo het en van die waarheid waarmee dit vervang moet word (Breed 2019a:[5, 10]). Daar word aan die beradene verduidelik wie die drie Persone van die goddelike Drie-eenheid is en wat dit vir die persoon in sy of haar situasie beteken. Die beradene word gelei om Efesiërs 6 se wapenrusting te verstaan, aan te neem en te gebruik (Breed 2019a:[6-8]).

In die derde fase neem die Woord ook 'n sentrale plek in wanneer die beradene begelei word om in 'n nuwe lewe te volhard. In hierdie fase is Osmer se 'pragmatic task' met die vraag 'How might we respond?' veral aan die orde. In die nuwe lewe breek die persoon met ou denkpatrone en die ou

8.Dit is duidelik dat $G$. Breed grondig met standpunte van 'n skrywer soos Dreyer (1999) verskil. Dreyer (1999:960-962) lewer byvoorbeeld ernstige kritiek op Louw (1993) se pastorale model omdat hy, volgens haar, die Bybel as gelyk aan God se openbaring beskou. Volgens Dreyer is die Bybel getuienisse van mense se geloof en ongeloof in God. lewenswyse wat op valshede gebou is, en word hy of sy deur die berader ondersteun om te volhard met ' $n$ lewe wat op die waarhede van die Woord gebou is (Breed 2019a:[4, 5, 10]).

Die vierde fase word ook ingerig volgens die eise van die Skrif. In hierdie fase gebruik G. Breed Skrifgedeeltes soos Jakobus 5:16, Efesiërs 4:32 en 1 Tessalonisense 5:14 om te motiveer en te verduidelik dat medegelowiges verantwoordelik is om ' $n$ beradene in sy of haar volharding in 'n nuwe lewe te ondersteun (Breed 2019a:[12]).

In 1:3-11 gee Petrus aan die Godsopenbaring 'n sentrale plek. Petrus sê volgens 1:4a dat Jesus Christus aan die apostels ${ }^{9}$

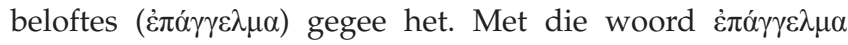
verwys hy na die beloftes in die Ou Testament aangaande die nuwe era van redding en seëninge wat God deur sy Messias 'n werklikheid sou laat word (Moo 2011:43). Petrus gebruik

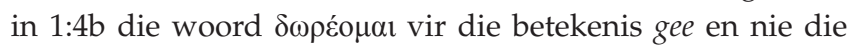
woord $\delta i \delta \omega \mu$ nie. Die woord $\delta \omega \rho \varepsilon ́ o \mu \alpha \iota$ wys op 'n meer formele aktiwiteit in die gee van 'n voorwerp (Louw \& Nida 1988:567). Daar kan afgelei word dat Petrus met die frase $\dot{\eta} \mu \mathrm{v} v$ $\dot{\varepsilon} \pi \alpha \gamma \gamma \dot{\varepsilon} \lambda \mu \alpha \tau \alpha \delta \varepsilon \delta \omega \dot{\eta} \eta \tau \alpha$ verwys na Jesus Christus wat aan sy geroepe (vgl. $\kappa \alpha \lambda \dot{\varepsilon} \omega$ in 1:3) apostels die evangelie toevertrou het. Hulle is uitgestuur om die blye boodskap dat die beloftes van God deur Jesus Christus se oorwinning 'n werklikheid geword het, te verkondig. Hierdie afleiding word ondersteun deur die feit dat Petrus ook in die res van die brief (vgl. 1:16 sowel as 3:2) die verkondiging van die apostels aan die lesers beklemtoon (Kruger 2020:8-10).

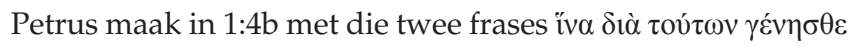

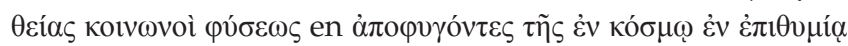
$\varphi \theta 0 \rho \tilde{\alpha} \varsigma$ duidelik dat Jesus Christus se beloftes aan die apostels gevolge vir die lesers ingehou het. Hierdie twee frases word later in hierdie artikel in besonderhede bespreek. Dit is egter nou van belang om daarop te wys dat Petrus met die aoristus werkwoord $\gamma \varepsilon \dot{v} \eta \sigma \theta \varepsilon$ in die eerste frase aandui dat die lesers, as gevolg van die beloftes wat die apostels ontvang het en wat die lesers in geloof aanvaar het, ${ }^{10}$ 'n nuwe staat of toestand verkry het. Die woord rívoua wys in 1:4 op die betekenis om 'n staat of toestand te verkry (Louw \& Nida 1988:154). Petrus

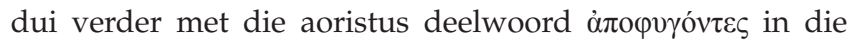
tweede frase aan wat die gevolg van die lesers se nuwe staat

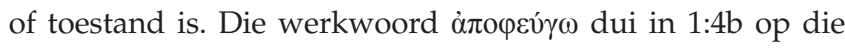
betekenis om veiligheid te verkry deur uit gevaar te ontsnap (Louw \& Nida 1988:240). Dit blyk dat Petrus in 1:4 duidelik maak dat die verkondiging van die boodskap waarmee Jesus Christus die apostels uitgestuur het en deur die lesers geglo is, ingrypende gevolge vir die lesers ingehou het.

Dit is belangrik om dit wat Petrus volgens 1:4 sê, in die konteks van die hele brief te verstaan. Dit is uit die volgende voorbeelde in die brief duidelik dat die apostel aanvaar dat

9. Breed en Jordaan (2000a:215-216) en Van Houwelingen (1988:100-102) toon aan
dat Petrus in 1:3-4a met ñũv nie na alle gelowiges verwys nie, maar na die apostels dat Petrus in 1:3-4a met nuĩv nie na alle gelowiges verwys nie, maar na
asook dat daar in 1:3 na Jesus Christus se goddelike krag verwys word.

10.Die feit dat Petrus reeds in 1:1 daarop wys dat die lesers geloof ( $\pi$ í⿴囗⿱一一) ) ontvang het en ook in 1:5 laat blyk dat hulle oor geloof ( $\pi$ íotıc) beskik, dui aan dat hy in 1:4b veronderstel dat die lesers die beloftes in geloof aanvaar het. 
dit wat God in die Ou Testament sowel as wat Hy deur Jesus Christus openbaar het, die onwaarhede van die vals leraars ontmasker en ook aan die lesers die regte koers aandui. Die vals leraars het volgens 1:16-18 die koms van die Here betwyfel (Bauckham 1983:155; Earl 2000:337). Die skrywer bestry die leraars deur te wys op dit wat die apostels aangaande God se openbaring op die berg van verheerliking aan die lesers bekend gemaak het (vgl. $\gamma v \omega \rho i ́ \zeta \omega$ in 1:16; Davids 2006:201). In 1:19 beklemtoon Petrus die lig wat die profetiese woord bied wanneer hy dit met 'n lamp wat in 'n donker plek skyn, vergelyk (Van Houwelingen 1993:49-50). Dit is ook duidelik dat Petrus aanvaar dat die Skrif goddelike gesag dra. In 1:21 maak hy duidelik dat mense wat geprofeteer het, meegevoer is deur die Heilige Gees (Hafemann 2014:320). Petrus gebruik ook gedeeltes uit die Ou Testament om die $\mathrm{d}$ walings van die vals leraars te ontbloot $(2: 4-9,15-16 ; 3: 5-8)$ en om die lesers pastoraal te bemoedig $(2: 4-9 ; 3: 2$, 8-9 en 13; Breed 1995:216-320).

\section{Die noodsaak van wedergeboorte}

In ooreenstemming met G. Breed se metateoretiese vertrekpunt dat die Woord van God in die pastoraat bepalend is, aanvaar hy ook dat die mens soos in die Woord geopenbaar word, deur God as volmaakte wese geskape is. Hy beklemtoon dat die mens geskape is om in 'n noue verhouding met God, in 'n oop verhouding met medemense en as koning binne die skepping, te leef. G. Breed dui egter ook uit die Skrif aan dat die sondeval dit alles verander het. Mense beantwoord nie meer aan hulle skeppingsdoel nie. G. Breed sê dat berading vir 'n mens in hierdie toestand nie goeie vrugte sal oplewer nie. In hierdie toestand is die mens nie in staat om te begryp wat die waarheid uit God se Woord is nie, en die mens kan ook nie doen wat God in sy Woord beveel nie (Breed 2013:2-3; 2019a:[11]). In hierdie toestand ontstaan daar, volgens G. Breed, by die mens 'n 'God-shaped emptiness'. Die mens probeer om hierdie leegheid met eie oplossings te vul. Omdat hierdie soort vervulling nie volgens God se Woord is nie, bring dit net tydelike verligting en dit lei nie tot die ware oorvloedige lewe wat God aan sy kinders gee nie (Breed 2019a:[4-6]; Nickols 2019:167).

Breed (2013:3; 2019a:[8]) beklemtoon egter ook dat die mens volgens die Bybel 'n nuwe lewe kan ontvang. Dit gebeur wanneer iemand wedergebore word deur die Heilige Gees. G. Breed gaan daarom in sy model van die veronderstelling uit dat iemand wat wedergebore is, wel met vrug pastorale begeleiding kan ontvang. Hy wys daarop dat wedergebore mense in staat is om die waarheid uit God se Woord te glo, om sonde in hulle lewe te oorwin en in geloofsvolwassenheid te groei.

Petrus stel op ' $n$ baie besondere manier in die opsomming van sy leer (1:3-11) die verandering in mense aan die orde. Daar is reeds in hierdie artikel aangedui dat Petrus die woord

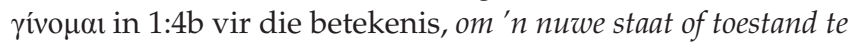
verkry, gebruik. Die nuwe staat van die lesers word in 1:4b

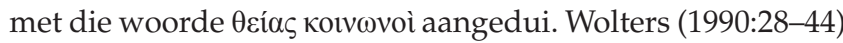
het in 'n studie oor 1 Petrus 1:4 aangetoon dat die vers binne die konteks van die verbond verstaan moet word. Anders as Käsemann (1964:179-180) wat oortuig is dat 1:4 'clearly marks the relapse of Christianity into Hellenistic dualism' en Kümmel (1963:93) wat dit as 'n 'timeless Hellenictic view of salvation' beskou, toon Wolters aan dat die skrywer nie met die woorde

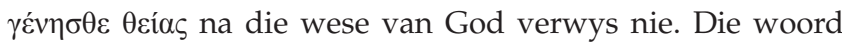

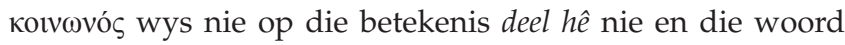

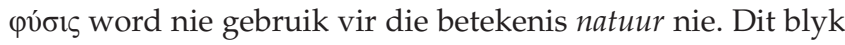
uit Wolters se studie (vgl. ook Breed \& Jordaan 2000a:

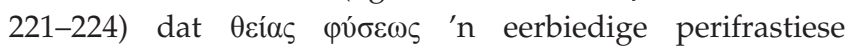
verwysing na God is en dat Petrus dus met die woorde $\theta$ cías

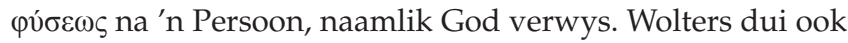

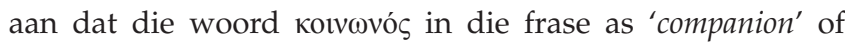
'partner' verstaan moet word. Dit word bevestig deur die feit

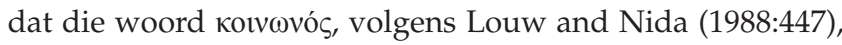
gebruik word vir die volgende betekenis: iemand wat saam met iemand anders deelneem aan ' $n$ onderneming. Wanneer 1:4b dus binne die konteks van die verbond verstaan word, maak Petrus in vers $4 \mathrm{~b}$ duidelik dat die lesers tot die besondere posisie van vennote van God oorgegaan het. Die woord

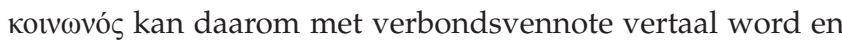
dit gee uitdrukking aan die besondere verbondsverhouding tussen God en mense - 'n verhouding wat op verskeie plekke in die $\mathrm{Ou}$ en Nuwe Testament beskryf word. In ooreenstemming met die verbondsverhouding wat in die res van die Skrif beskryf word (vgl. Grudem 2009:515-522), is hierdie nie 'n verhouding tussen gelykes nie, maar is dit God wat die voorwaardes van die verbond bepaal. Van die mens word verwag om dit in geloof te aanvaar en te gehoorsaam.

Petrus gebruik nie in 1:4, soos in 1 Petrus 1:3, die woord

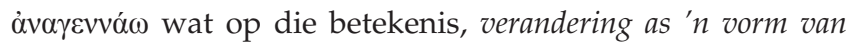
geestelike wedergeboorte (Louw \& Nida 1988:155), wys nie. Die feit dat hy egter met die woord yívouaı aandui dat die lesers in 'n nuwe staat of toestand kom, toon dat hy wel in 1:4 die wedergeboorte in gedagte het. Omdat Petrus sy tweede brief in ' $\mathrm{n}$ besondere literêre styl met ' $\mathrm{n}$ 'high-sounding manner of expression leaning toward the novel and bizarre, and careless about violating classic ideals of simplicity' (Reicke 1964:147, vgl. ook Watson \& Callan 2012:132-135) geskryf het, kan aanvaar word dat hy die wedergeboorte in 1:4 ook op hierdie besondere manier aandui.

Die toestand waarin die mense wat verbondsvennote geword

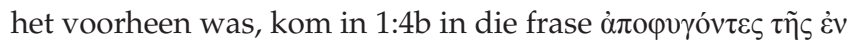

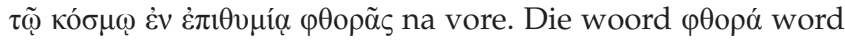
in 1:4 vir die betekenis, ' $n$ toestand van morele vuilheid en verdorwenheid, gebruik (vgl. Green 2008:187; Louw \& Nida $1988: 771)$. Hierdie staat van onreinheid en vuilheid is volgens $1: 4 b$, in die wêreld as gevolg van die sondige begeertes

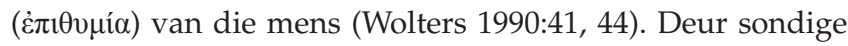
begeertes word mense gevangenes binne 'n staat van onreinheid en vuilheid. In 1:4b beklemtoon Petrus die ontvlugting ( $\dot{\alpha} \pi \circ \varphi \varepsilon v ́ \gamma \omega)$ uit hierdie staat. Omdat die lesers in die volgende verse aangespoor word om deugde by hulle geloof te voeg, kan aanvaar word dat die aoristus deelwoord

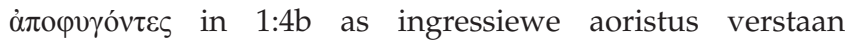
moet word, wat die begin van 'n handeling aandui 
(Jordaan 2014:204). Die lesers wat in 'n besondere verbondsvennootskap met God gekom het, het begin om die staat van onreinheid te ontvlug.

In die res van 2 Petrus ontvang die onmag van die mens wat nie wedergebore is nie, baie aandag. In 2:19 sê Petrus dat die vals leraars vryheid belowe. Hulle is egter slawe ( $\delta$ oṽ $\lambda \mathrm{o}$ ) van die morele vuilheid en verdorwenheid ( $\varphi \theta 0 \rho \alpha ́)$ waarvan die gelowige lesers reeds begin ontvlug het. Die magteloosheid van ongelowiges in hulle sondige staat, word in 2:12 verder beklemtoon wanneer Petrus skryf dat hulle soos diere instinkmatig ( $\varphi v \sigma ı \kappa o ́ \varsigma) ~ o p t r e e$.

\section{Intense verhouding met God}

In $\mathrm{G}$. Breed se model, ontvang die verhouding tussen 'n beradene en God besondere aandag. Alleen in 'n lewende verhouding met God kan mense die sin van hulle lewe verstaan op 'n wyse wat God verheerlik en sodoende vreugde en vervulling in hulle lewe vind (Breed 2013:2; 2019a:[4, 6]). Volgens G. Breed se teoretiese raamwerk vir pastorale berading, is daar drie ankerpunte vir die beradene in die verhouding met God. Die eerste ankerpunt is die beradene se kennis van God die Vader. Gelowige beradenes mag seker wees van die Vader se mag en wil om hulle as sy kinders te versorg. Die tweede ankerpunt is geleë in die beradene se verhouding met Jesus Christus. Gelowige beradenes word begelei om die verlossing wat Jesus Christus deur sy soendood bewerk het, te ken en met die sekerheid te leef dat niks hulle van God se liefde sal kan skei nie. Die derde ankerpunt vir die beradene is in die werk van die Heilige Gees geleë. Die beradene moet die Heilige Gees as die Helper of Trooster ken, as die Een wat insig gee en die krag verleen om lief te hê en om aan God gehoorsaam te leef. Sy of haar lewe moet volgens hierdie sekerheid ingerig word (Breed 2019a:[6-8]; 2019b:7-8; Nickols 2019:142-144; Pretorius 2017:199-204).

Petrus gee in 1:3-11 besondere aandag aan gelowiges se verhouding met God. Die klem in 1:3-11 val op die verhouding met Jesus Christus. Petrus gebruik in sy tweede

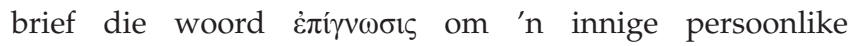
verhouding aan te dui (Breed \& Jordaan 2000a:213-214; Green 2008:193). In 1:3 maak hy met die voorsetselfrase Si⿳亠 $\dot{\varepsilon} \pi$ $\uparrow \omega ́ \sigma \varepsilon \omega \varsigma$ duidelik dat 'n innige persoonlike verhouding met Jesus Christus die instrument was wat sekere dinge aan die apostels geskenk het deur goddelike krag. In 1:8 word die innige en persoonlike verhouding met Jesus Christus ('I $\eta \sigma o v$ X deugde by hulle geloof moet voeg. Hy verseker ook die lesers

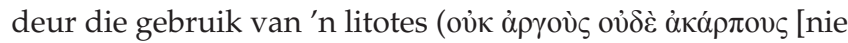
ledig of onvrugbaar nie]) dat, indien hulle die deugde by hulle geloof voeg, daar goeie resultate sal wees in hulle verhouding met Jesus Christus. Deur die deugde by hulle

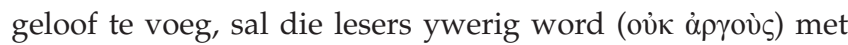
betrekking tot hulle verhouding met Jesus Christus en sal

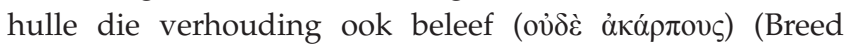
1994:115, 143; Harink 2009:147).
In die aanhef van die brief neem die verhouding met Jesus Christus ook 'n belangrik plek in. In 1:2 dui Petrus aan dat

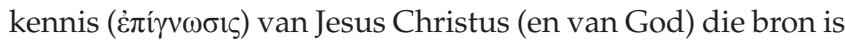
waaruit en die middel is waarmee genade en vrede vir die lesers vermeerder kan word (Breed 1994:102).

\section{Verandering en insig}

Volgens G. Breed (2013:3-4; 2019a:[4]) se model hang verandering in die mens ten nouste saam met die mens se gedagtes en oortuigings. Hy wys daarop dat God die mens as 'n wese in gesprek geskape het - in gesprek met God, met ander mense, met die skepping en met hom- of haarself. Mense is voortdurend innerlik in gesprek met hulleself en probeer sin maak van die lewe. Hierdie gesprek bepaal die mens se reaksie op gebeure of situasies in sy of haar lewe. Besluite wat die persoon neem, kan by hom of haar 'n oortuiging word en by herhaling, 'n lewenspatroon.

Wanneer 'n persoon se besluite, oortuigings en lewenswyse op leuens gebou is en deur herhaling 'n vaste lewenspatroon geword het, is verandering by so 'n mens baie moeilik (Breed 2013:4). Verandering kan alleen plaasvind wanneer die beradene insig kry in die wortel van sy of haar probleem. Die persoon moet begryp wat die waarheid volgens God se Woord is waarop hy of sy besluite, oortuigings en 'n lewenswyse moet bou, sowel as wat dit inhou om nuwe oortuigings en 'n nuwe lewenswyse op hierdie waarheid te bou (Breed 2019a:[4-5]).

Petrus lê in 1:3-11 sterk nadruk daarop dat sy lesers wat hulle standvastigheid in die geloof kan verloor (vgl. 3:17-18), oor insig moet beskik. Wanneer hy in 1:5-7 die gelowiges aanspoor om die geloof wat hulle ontvang het (vgl. 1:1) te verryk, is een van die deugde wat hulle moet byvoeg 'kennis'

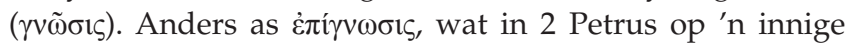
persoonlike verhouding dui, word $\gamma v \tilde{\omega} \sigma ı \varsigma$ in 2 Petrus gebruik om onderskeidingsvermoë aan te dui (Breed \& Jordaan 2000b:430-431). Die lesers aan wie ' $n$ vals leer verkondig is (2:1-2), moet hulle geloof verryk met onderskeidingsvermoë sodat hulle die valshede wat aan hulle verkondig is

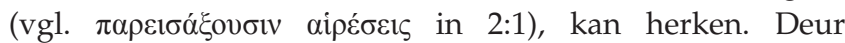
onderskeidingsvermoë sal hulle ook weet dat dit wat die apostels verkondig het, die waarheid is waarvolgens hulle hul lewe moet inrig (vgl. 3:2).

Dat Petrus die deug van onderskeidingsvermoë as belangrik ag, word ook duidelik wanneer hy aan die einde van die brief (3:17-18) die lesers oproep om te sorg dat hulle in onderskeidingsvermoë groei $(\gamma \nu \tilde{\omega} \sigma ı)$. Hy maak

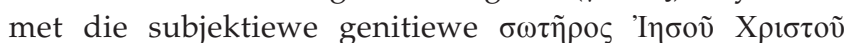
(3:18) duidelik dat onderskeidingsvermoë iets is wat die gelowige van die Here en Verlosser, Jesus Christus, ontvang (Breed 1994:338).

In 1:9 stel Petrus op 'n besondere manier die belangrikheid van insig by die gelowiges aan die orde. Hy verwys na

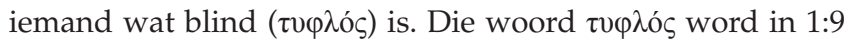
vir die betekenis onvermoë om te verstaan (Louw \& Nida 
1988:385) gebruik. Hierdie onvermoë verduidelik hy eerstens met die deelwoord $\mu v \omega \pi \alpha ́ \zeta \omega v$ (Breed \& Jordaan 2000c:586). Met die woord $\mu v \omega \pi \alpha ́ \zeta \omega$ wys hy op iemand wat 'n uitsonderlike gebrek het aan die vermoë om inligting te gebruik om tot die regte evaluering te kom (vgl. Louw \& Nida 1988:386). Daar kan aanvaar word dat Petrus in 1:9 verwys na mense se onvermoë om die leer van die vals leraars en die leer van die apostels te evalueer. Iemand wat

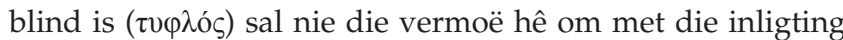
tot hulle beskikking, tot die regte evaluering te kom nie. Hulle sal hulle lewe inrig volgens die leuens wat die vals leraars verkondig het.

\section{Eksterne en interne motivering}

Breed (2017; 2019a:[6, 10]) waarsku dat wanneer die motivering by die gelowige om te verander van buite die gelowige kom, die verandering nie volhoubaar sal wees nie. Hy bespreek drie siklusse om dit te verduidelik, naamlik die verslawing-siklus, die wet-siklus en die genade-siklus. Volgens die verslawing-siklus probeer ' $n$ gelowige ' $n$ geldige behoefte soos die behoefte aan aanvaarding, met 'n sondige optrede, byvoorbeeld die kyk van pornografie, bevredig. Hierdie oplossing van die persoon se behoefte bevredig egter nooit op die lang duur nie omdat dit nie die ware behoefte bevredig nie. Die middel waarmee gepoog word om die behoefte te bevredig, is dikwels verslawend. Omdat die gelowige die sondigheid daarvan besef, probeer hy of sy met die sonde of verslawing breek. Omdat die behoefte nie werklik bevredig word nie, ontspring daar na 'n tyd 'n obsessiewe behoefte om toe te gee aan die verslawing of sonde en keer die persoon terug na die ou lewe van sonde of verslawing.

G. Breed verduidelik dat die wet-siklus baie dieselfde is as die sonde-siklus. Die motivering om te verander kom ook van buite die persoon. Dit kan die wet van God, byvoorbeeld vrees vir God se straf of die verwagtinge van ander mense wees wat die persoon motiveer om te verander. Omdat die motivering tot 'n nuwe lewe 'n eksterne motivering is, val die persoon op die lang duur, net soos met die verslawing-siklus, terug in sy of haar ou lewe.

In die genade-siklus is die motivering om met die sonde of verslawing te breek, nie ekstern nie. Die motivering om met denkpatrone en 'n leefwyse wat op leuens gebou is, te breek, is God se genade in Christus. Volgens hierdie siklus leer die beradene die genadige vergifnis en die onvoorwaardelike liefde en aanvaarding deur God ken. Die persoon kies bewustelik daarvoor en vind vertroosting daarin. Die begrip van hierdie genade van God voorkom dat die beradene weer in die ou lewe vasdraai. Met die sekerheid van God se vergifnis, sy aanvaarding en sy liefde kan die beradene, wanneer hy of sy struikel, teruggaan na God en weer met vasberadenheid die stryd om 'n nuwe lewe aanpak. Met die sekerheid van hierdie genade, word die tydperk van 'n terugval in die ou lewe en die diepte van die terugval ook verminder (Breed 2019a:[6, 10]).
God se genade as motivering word in 2 Petrus 1:9 op 'n besondere manier aan die orde gestel. Daar is reeds in hierdie artikel daarop gewys dat Petrus in 1:9 met die woord $\tau v \varphi \lambda$ ó $\varsigma$ mense aandui wat 'n onvermoë het om te verstaan, dat hulle nie inligting kan evalueer nie. Volgens 1:9 bestaan hulle blindheid ook daarin dat hulle vergeet (vergelyk die

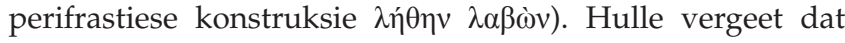
hulle van hulle vorige sondes gereinig is. Skrywers soos Paulsen (1992:112) en Van Houwelingen (1993:38-39) toon oortuigend aan dat die skrywer met die frase van die vorige sondes gereinig is, na die doop verwys. Mense wat blind is ( $\left.\tau \cup \varphi \lambda{ }^{\prime} \varsigma\right)$ se blindheid bestaan dus ook daarin dat dít wat die doop vir gelowiges bevestig, naamlik dat Christus hulle van hul sondes gereinig het, nie meer vir hulle ter sake is nie. Petrus hou dus in 1:9 God se vergifnis in Jesus Christus soos dit in die doop be-teken word, aan die lesers voor as motivering tot 'n lewe volgens die leer van die apostels.

\section{Volharding in 'n nuwe lewe}

Breed (2013:6) beklemtoon dat verandering in 'n gelowige se lewe 'n langsame en uiters moeilike taak is wat volharding vereis. Dit is veral in die derde en vierde fase van G. Breed se pastorale model waarin die volharding deur die beradene op die voorgrond staan. In hierdie twee fases word die beradene ondersteun om met'n lewenspatroon wat op leuens gebou is, te breek en met die krag van die Heilige Gees 'n nuwe lewenspatroon, wat gebou is op die waarheid van God se Woord, aan te leer. Daar moet by die beradene 'n ferm besluit wees om in die toekoms geen ruimte te laat vir emosies en 'n lewenspatroon wat op leuens gebou is nie(Breed 2019a:[8, 10]). Die beradene moet deur herhaling en kondisionering meer en meer volgens die waarheid dink, voel en optree. Die gewoonte om volgens leuens op te tree, moet deur 'n nuwe gewoonte vervang word. Op dié wyse, sê Breed (2019b:8-9), verander die persoon nie maar net sy of haar gewoontes nie, maar verander hy of sy al hoe meer na die beeld van Christus.

Gelowiges se volharding is ook in 1:3-11 ter sprake. Petrus gee

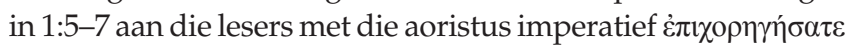
opdrag om deugde by hulle geloof te voeg. Hy maak gebruik van 'n klimatiese opboupatroon (sorites). Fischel (1973) verduidelik 'n sorites:

$[A s]$ a set of statements which proceed, step by step, through the force of logic or reliance upon a succession of indisputable facts, to a climactic conclusion, each statement picking up the last key word (or key phrase) of the preceding one. (bl. 119; vgl. ook Viljoen 2012:526)

Deur in die sorites telkens saam met die voorsetsel $\dot{\varepsilon} v$ 'n datief te gebruik, maak Petrus duidelik dat die deugde 'n geheel is wat die lesers by die gronddeug, geloof ( moet voeg. Dit wys op 'n geloofslewe gevul met deugde - 'n lewe volgens God se wil (Breed \& Jordaan 2000b:429-430). Dit is belangrik om daarop te let dat volharding ( een van die deugde is wat gelowiges by hulle geloof moet voeg (1:6). Gelowiges moet volhard in 'n lewe gevul met deugde. Hulle moenie optree soos die mense na wie Petrus in 2:20 verwys nie - mense wat uit die besoedeling van die 


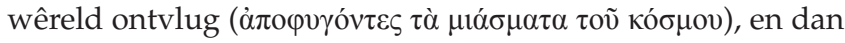
weer daarin verstrik raak en daardeur oorwin word ( $\pi \alpha \dot{\lambda} \lambda \mathrm{w}$ $\dot{\varepsilon} \mu \pi \lambda \alpha \kappa \varepsilon ́ v \tau \varepsilon \zeta \dot{\eta} \tau \tau \tilde{\omega} \nu \tau \alpha 1)$.

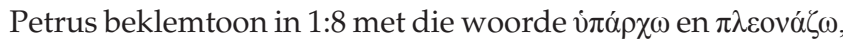
dat die lesers nie 'n geloofslewe gevul met die deugde halfhartig en oppervlakkig moet aanpak nie. Met die woord vंá́ $\rho \omega$ maak hy duidelik dat die lesers eienaarskap van die deugde moet neem (Louw \& Nida 1988:158); en met die

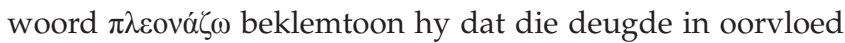
in hulle lewe teenwoordig moet wees (Louw \& Nida 1988:599).

Uit die konteks van die brief is dit duidelik hoekom die spesifieke deugde aan die lesers voorgehou word. Die lewe wat in 1:5-7 beskryf word, staan in direkte teenstelling met die lewe van die vals leraars wat in 2:1-22 beskryf word.

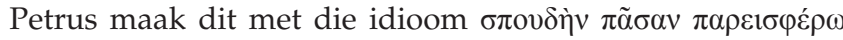
(Louw \& Nida 1988:663) in 1:5 duidelik dat die lesers alles moet inspan om te volhard in 'n lewe wat radikaal verskil van die lewe van die vals leraars.

In 1:10 word die lesers in hulle volharding versterk deur op

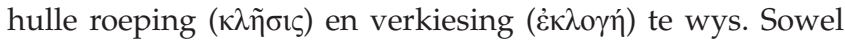

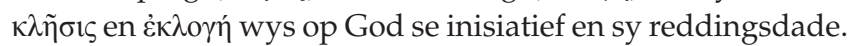
Voor die grondlegging van die wêreld het Hy mense deur genade in sy Seun Jesus Christus verkies (Ef 1:4) en in tyd roep Hy die mense wat Hy verkies het deur die verkondiging van die evangelie (2 Tim 2:14). Hierdie 'roeping' is nie maar 'n uitnodiging nie. Dit is eerder 'n 'divine summons' (Green 2008:200-201). In volgorde gaan die verkiesing die roeping vooraf, maar Petrus lig die volgorde uit waarop die mens hierdie verlossingsdade van God ervaar. Wie geroep is en tot geloof kom, kom daarna tot die besef dat hy of sy reeds voorheen deur God verkies is (vgl. Green 1987:83-84). Petrus roep die lesers op om hulle roeping en verkiesing vas te maak

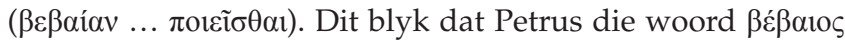
in 1:10 in die semantiese veld kennis en in die subdomein goed bekend, duidelik toon, openbaar gebruik vir die betekenis as waar bekend, seker, gesertifiseer (Louw \& Nida 1988:340). Van Houwelingen (1993:40) toon oortuigend aan dat dit nie in 1:10 oor medewerking met God in die roeping en verkiesing

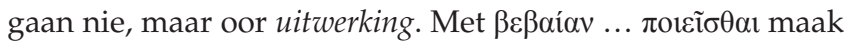
Petrus dus duidelik dat die lesers moet bevestig dat hulle deur God geroep en verkies is. Hierdie bevestiging moet hulle met oorgawe doen ( $\sigma \pi 0 v \delta \alpha ́ \zeta \omega-1: 9)$. Dit is duidelik dat die lesers aangespoor word om met oorgawe in 'n lewe vol deugde te volhard deur die gevolge van so 'n lewe aan te toon. Hulle wat volhard, ontvang bevestiging van 'n onwankelbare sekerheid, van iets wat God tot stand gebring het, naamlik dat hulle God se geroepenes en uitverkorenes is.

Petrus spoor die lesers in 1:10-11 ook verder aan om te volhard. Hy sê dat, indien die lesers sekere dinge ( $\tau \alpha \tilde{\tau} \tau \alpha)$ doen, hulle nooit sal struikel $(\pi \tau \alpha i \omega)$ nie. Die woord $\tau \alpha \tilde{v} \tau \alpha$ verwys na die byvoeging van die deugde van verse $5-7$ (Green 2008:201). Wanneer Petrus sê dat die lesers nooit sal struikel nie, bedoel hy nie dat die lesers nooit sal sondig nie. Petrus het die toegang tot die koninkryk wat hy in 1:11 ter sprake bring, in die oog. As die lesers hulle aan 'n lewe gevul met deugde toewy (1:5-7), mag hulle seker wees dat hulle nie sal struikel nie 'on the path to God's kingdom and thus fail to arrive' (Davids 2006:189). Mense wat hulle lewe volgens God se wil inrig, sal op 'n besondere manier toegang tot die koninkryk verkry. Daar sal ryklik aan hulle toegang verleen

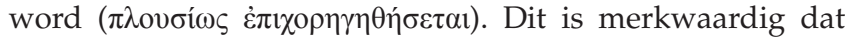
Petrus sê dat die koninkryk waartoe hierdie mense toegang sal verkry, aan Jesus Christus behoort en dat Jesus die

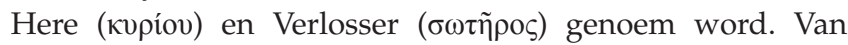
Houwelingen (1993) sê:

Onze Heer en Redder is tegelijk de eeuwige Koning. Voor Hem gaan alle deuren van het hemelrijk wijd open (Op. 3, 7). Zondige mensen, aan zijn hand binnengebracht, krijgen uiteindelijk toch een royale entree in het rijk van het Koning Christus. En ook de ontvangst zal vorstelijk zijn! (bl. 41)

Die lesers word dus in 1:10-11 tot volharding aangespoor. Wie volhard, mag met sekerheid uitsien om op grond van Jesus Christus se verlossingswerk, ryklik toegang tot sy ewige koninkryk te verkry.

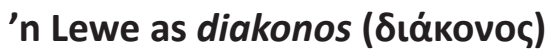

Dit is volgens G. Breed se beradingsmodel belangrik dat 'n beradene begelei moet word om sy of haar lewe in te rig volgens die lewe van iemand wat in die Bybel 'n diakonos

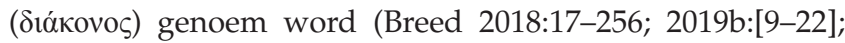
Breed \& Kruger 2014:6-10).

Breed (2012a:3-4; 2012b:4-5; 2018:234) toon aan dat die diakon-woordgroep in die Nuwe Testament nie uitsluitlik op die betekenis nederige dienswerk of die werk van ' $n$ kelner of slaaf wys nie. In navolging van Collins (1992) sê G. Breed dat dit eerder die werk van ' $n$ verteenwoordiger of 'n gesant beskryf. Nadat G. Breed verskeie Skrifgedeeltes bestudeer het waar

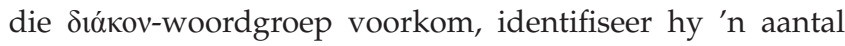
konsepte (temas) wat uit die woordgroep geformuleer kan word (Breed 2018:229-242; 2019b:[9-19]). Volgens Breed (2019b:[9]) moet die berader die beradene oortuig om 'according to the directions and grace given for a life as diakonos of Christ ...' te leef (vgl. ook Breed 2013:5). Vir hierdie artikel is dit ter sake dat Breed (2018:250) aandui dat die Siókovwoordgroep soms ten nouste verbind is met sorg, gasvryheid, meelewing en liefde.

Wanneer Petrus in die sorites (1:5-7) die spesifieke deugde noem wat die lesers se lewe in hulle omstandighede moet kenmerk, is dit opvallend dat die laaste twee deugde wat hy noem, die lesers se verhouding met ander mense na vore bring. Die lesers moet volgens 1:7 liefde vir medegelowiges ( $\left.\varphi \imath \alpha \delta \varepsilon \lambda \varphi^{\prime} \dot{\alpha} \alpha\right)$ en liefde vir alle mense ( $\left.\dot{\alpha} \gamma \alpha \dot{\pi} \tau\right)$ ) (Van Houwelingen 1988:111-112) by hulle geloof voeg. Omdat deugde in 'n sorites na 'n klimaks opbou (Bauckham 1983:174-176), kan aanvaar word dat Petrus met die sorites in 1:5-7 die lesers se liefde vir medegelowiges sowel as hulle liefde vir alle mense beklemtoon.

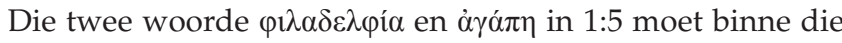
konteks van die vals leraars se verhoudings met ander 
mense verstaan word. Petrus laat in die brief geen twyfel oor die liefdeloosheid van die vals leraars wat hy bestry nie. Hy maak duidelik dat hulle op hulle eie belang ingestel is. Hulle

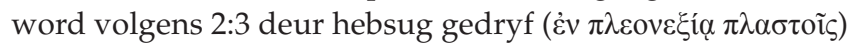
en, volgens 2:14, het hulle harte wat in hebsug geoefen

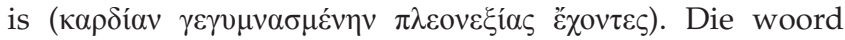
$\pi \lambda \varepsilon$ ove $\xi i \alpha$ dui in 2:3 op die betekenis om as gevolg van hebsug voordeel uit iemand te trek (Louw \& Nida 1988:758) en

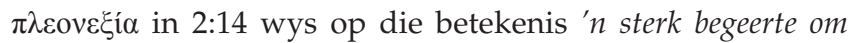
meer en meer materiële besittings te verkry (Louw \& Nida 1988:291). Die vals leraars se liefdeloosheid word ook in 2:3

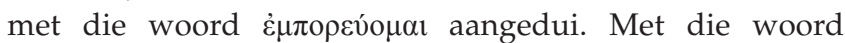
$\dot{\varepsilon} \mu \pi о \rho \varepsilon v ́ o \mu \alpha$ wys Petrus daarop dat die leraars uit ander voordeel trek deur voor te hou dat iets meer werd is as wat dit werklik is (Louw \& Nida 1988:759). Petrus lê veral klem op die vals leraars se liefdelose optrede teenoor gelowiges. Met die woord $\delta \varepsilon \lambda \varepsilon \alpha ́ \zeta \omega$ (Louw \& Nida 1988:775) wys hy in 2:14 daarop dat hulle ingestel is om gelowiges wat nie standvastig is nie, te laat sondig. In teenstelling met die vals leraars moet die lesers se lewe van liefde getuig. Die lesers moet alle ywer aan die dag lê om medegelowiges en alle mense lief te hê. Anders as die vals leraars, moet hulle nie maar net op hulle eie belang ingestel wees nie. In plaas daarvan dat hulle mense uitbuit, moet hulle in liefde na die mense se belange omsien.

\section{Gevolgtrekking}

Binne die konteks van die brief, bied 1:3-11 Skrifgronde vir verskeie belangrike elemente van $\mathrm{G}$. Breed se pastorale bybelse model. Uit 1:3-11 kan aangetoon word dat, in ooreenstemming met $\mathrm{G}$. Breed se metateoretiese vertrekpunt, die Bybel as die Woord van God 'n sentrale plek in die pastoraat behoort in te neem. Wanneer die Bybel 'n sentrale plek in berading inneem, is dit moontlik dat daar ingrypende verandering in 'n beradene se lewe kan kom. Die Bybel dra goddelike gesag en sou daarom as vaste norm in berading gebruik kan word om valshede waarop 'n persoon sy of haar lewe bou, sowel as die waarhede waarop die persoon sy of haar lewe behóórt te bou, aan te dui.

Die noodsaak dat 'n beradene wedergebore moet wees om met vrug berading te kan ontvang, soos dit in G. Breed se model beklemtoon word, kan ook in 1:3-11 begrond word. Petrus beklemtoon dat mense deur die wedergeboorte verbondsvennote van God word. Verbondsvennote van God is, anders as die ongelowiges, nie magteloos in ' $n$ sondige lewe vasgevang nie. Hulle het begin om die staat van morele onreinheid en vuilheid te ontvlug.

Die standpunt van G. Breed dat 'n persoon se verhouding met God in berading ' $n$ sentrale plek behoort in te neem, vind begronding in 1:3-11. Dit is in besonder die verhouding met Jesus Christus wat in die opsomming van die apostel se leer aangedui kan word. Uit 1:3-11 kan aangedui word dat 'n beradene, in die verryking van sy of haar geloof, 'n innige en persoonlike verhouding met Jesus Christus as doel behoort te stel. Wanneer 'n persoon sy of haar geloof verryk, mag hy of sy met sekerheid heerlike resultate verwag in die verhouding met Jesus Christus. 'n Persoonlike verhouding met Jesus Christus (en met God) is die bron waaruit en die middel waarmee genade en vrede vir die beradene vermeerder kan word.

Dit is duidelik dat die element van verandering deur insig, soos dit in G. Breed se model aan die orde is, in 1:3-11 begrond kan word. Petrus maak dit duidelik dat Jesus Christus aan gelowiges onderskeidingsvermoë gee en dat gelowiges in onderskeidingsvermoë moet groei. Wanneer gelowiges oor onderskeidingsvermoë beskik, sal hulle valshede waarop hulle hul lewe gebou het, kan herken. Hulle sal ook insig hê in die waarhede van die Godsopenbaring en hulle lewe daarvolgens kan inrig.

Die beklemtoning van die genadige vergifnis, die onvoorwaardelike liefde en aanvaarding deur God in die beradingsmodel van G. Breed, kan in 1:3-11 begrond word. Dit is uit die opsomming van die apostels se leer duidelik dat die verlossing wat Jesus Christus bewerk het, die dryfveer tot 'n nuwe lewe vir die gelowige moet wees. Hierdie verlossing wat die doop vir elke gelowige be-teken, moet die gelowige begelei op die pad na 'n nuwe lewe.

G. Breed se beklemtoning dat 'n beradene se volharding in 'n nuwe lewe prioriteit moet geniet, kan ook in die opsomming van Petrus se leer (1:3-11) gefundeer word. Beradenes moet self alles in die stryd werp om nie weer in die sondige lewe verstrik te raak waarin hulle voorheen vasgevang was nie. Uit 1:3-11 sou beraders gelowiges tot volharding kon aanspoor deur op die heerlike gevolge te wys wanneer daar met 'n lewe in gehoorsaamheid aan God volhard word. Deur in ' $n$ nuwe lewe van gehoorsaamheid te volhard, bevestig gelowiges dat hulle God se geroepenes en uitverkorenes is en mag hulle met sekerheid uitsien om op grond van Jesus Christus se verlossingswerk ryklik toegang tot sy ewige koninkryk te verkry.

Die element in G. Breed se model dat 'n beradene begelei moet word om as diakonos van Christus te leef, in besonder om sorg, gasvryheid, meelewing en liefde te betoon, kan in 1:3-11 gefundeer word. Petrus ag dit belangrik dat gelowiges, in hulle stryd om nie hulle standvastigheid te verloor nie, liefde vir medegelowiges en alle ander mense sal betoon.

\section{Erkenning Mededingende belange}

Die outeur verklaar dat daar geen finansiële of persoonlike verbintenis is met enige party wat hom nadelig kon beïnvloed in die skryf van hierdie artikel nie.

\section{Outeursbydrae}

D.G.B. was die enigste outeur betrokke by die skryf van die artikel.

\section{Etiese oorwegings}

Hierdie artikel volg alle etiese standaarde vir navorsing. 


\section{Befondsing}

Hierdie navorsing het geen spesifieke toekenning ontvang van enige befondsingsagentskap in die openbare, kommersiële of nie-winsgewende sektore.

\section{Data beskikbaarheidsverklaring}

Die deel van data is nie van toepassing op hierdie artikel nie, aangesien geen nuwe data in hierdie studie geskep of ontleed is nie.

\section{Vrywaring}

Die sienings en menings wat in hierdie artikel uitgedruk word, is dié van die outeur en weerspieël nie noodwendig die amptelike beleid of posisie van enige geaffilieerde verwantskap van die outeur nie.

\section{Literatuurverwysings}

Bauckham, R.J., 1983, Jude, 2 Peter, Word Books, Dallas. (Word Biblical Commentary, vol. 50).

Breed, D.G., 1994, 'Die kenmotief in 2 Petrus: 'n Eksegetiese studie', ThD-proefskrif, $\mathrm{PU}$ vir $\mathrm{CHO}$, Potchefstroom.

Breed, D.G. \& Janse van Rensburg, F., 2001, 'Paraatmaking teen immoraliteit in ' $n$ postmodernistiese samelewing: ' $n$ Hermeneuse van 2 Petrus 1:12-15', HTS Teologiese Studies/Theological Studies 57(1/2), 408-434. https://doi.org/ 10.4102/hts.v57i1/2.1871

Breed, D.G. \& Jordaan, G.J.C., 2000a, 'Verandering van die moreel-etiese situasie in Suid-Afrika, in die lig van die kenmotief in 2 Petrus 1:3-4', In die Skriflig 34(2) 207-229. https://doi.org/10.4102/ids.v34i2.594

Breed, D.G. \& Jordaan, G.J.C., 2000b, 'Geloofsverryking te midde van moreel-etiese verwarring in die lig van 2 Pet. 1:5-7', In die Skriflig 34(3), 423-436. https://doi org/10.4102/ids.v34i3.605

Breed, D.G. \& Jordaan, G.J.C., 2000c, 'Geloofsvolharding en moreel-etiese agteruitgang in die lig van die kenmotief in 2 Petrus 1:8-11', In die Skriflig 34(4), 577-593. https://doi.org/10.4102/ids.v34i4.616

Breed, D.G. \& Van Staden, C.W., 2015, 'A reformational Christian overview on suffering, guilt, failures, and related issues in psychiatry', in J.Z. Sadler, K.W.M. Fulford \& C.W. guilt, failures, and related issues in psychiatry', in J.Z. Sadler, K.W.M. Fulford \& C.W.
van Staden (eds.), The Oxford handbook of psychiatric ethics, pp. 559-583, van Staden (eds.), The Oxford
Oxford University Press, Oxford.

Breed, G., 2012a, 'Nuut gedink oor die wese en inhoud van die dienswerk van die diaken', HTS Teologiese Studies/Theological Studies 68(1), 1-8. https://doi. org/10.4102/hts.v68i1.1059

Breed, G., 2012b, "n Begronde bedieningsmodel vir die diakonia van die gemeente', HTS Teologiese Studies/Theological Studies 68(2), 1-11. https://doi.org/10.4102/ hts.v68i2.1107

Breed, G., 2013, 'Metateoretiese vertrekpunte ten opsigte van wetenskaplike navorsing in die Pastorale Wetenskap', In die Skriflig/In Luce Verbi 47(1), 1-8. https://doi.org/10.4102/ids.v47i1.96

Breed, G., 2017, 'Help to the pornography addicted by the embodiment to love', paper presented at the IAPT Conference, University of Oslo, Norway, 20th April.

Breed, G., 2018, 'The diakon-word group in the New Testament and congregational ministry', ThD thesis, Radboud University, Nijmegen.

Breed, G., 2019a, PAST122 "n Bybelse pastorale model', lesings 1-10, NoordwesUniversiteit, Potchefstroom.

Breed, G., 2019b, 'Living as a diakonos of Christ and pastoral care to the narcissistically entitled person', inaugural address presented at the North-West University, Potchefstroom, 14th February.

Breed, G. \& Kruger F.P., 2014, "n Prakties-teologiese besinning oor die begeleiding en toerusting van kinders tot dienswerk as ' $n$ weg tot die navolging van die gesindheid van Christus', HTS Teologiese Studies/Theological Studies 70(2), 1-11. https://doi. org/10.4102/hts.v70i2.1373

Butticaz, S., 2016, 'The construction of Apostolic memories in the light of two New Testament Pseudepigrapha (2 Tm and $2 \mathrm{Pt}$ )', Annali di storia dell' esegesi 33(2), 341-363.

Charles, J.D., 1997, 'Virtue amidst vice. The catalog of Virtues in 2 Peter 1', Journal for the Study of the New Testament, suppl. ser. 150

Coetzee, J.C., 1988, 'Gedagtestruktuurontleding en die eksegese van die Heilige Skrifte', in J.C. Coetzee (red.), Koninkryk, Gees en Woord, pp. 19-37, NG Kerkboekhandel, Pretoria.

Collins, J.N., 1992, Are all Christians ministers?, Liturgical Press, Collegeville, PA.
Cotterell, P. \& Turner, M., 1989, Linguistics and biblical interpretation, InterVarsity Press, Downers Grove, IL.

Danker, F.W., 1978, '2 Peter 1: A solemn decree', The Catholic Biblical Quarterly 40(1), 64-82.

Davids, P.H., 2006, The letters of 2 Peter and Jude, Eerdmans, Grand Rapids, MI. (The Pillar New Testament Commentary).

Donelson, L.R., 2010, I \& II Peter and Jude: A commentary, Westminster John Knox Press, Louisville, KY. (The New Testament Library).

Dreyer, Y., 1999, 'Refleksie op twee pastorale modelle, Deel 1: Die pastor as vertolkerdie ontmoetingsmodel', HTS Teologiese Studies/Theological Studies, 55(4), 943-963. https://doi.org/10.4102/hts.v55i4.1644

Earl, R., 2000, Reading 1 Peter, Jude, and 2 Peter: A literary and theological commentary, Smyth \& Helwys, Macon, GA.

Fee, D.G., 2009, New Testament exegesis: A handbook for students and pastors, Westminster John Knox Press, Louisville, KY.

Fischel, H.A., 1973, 'The uses of sorites (climax, gradatio) in the Tannaitic period' Hebrew Union College annual 44, 119-151.

Green, G., 2008, Jude and 2 Peter, Baker Academic, Grand Rapids, MI. (Baker Exegetical Commentary on the New Testament).

Green, M., 1987, The second epistle general of Peter and the general epistle of Jude: An introduction and commentary, Eerdmans, Grand Rapids, MI. (The Tyndale New Testament Commentaries).

Grudem, W.A., 2009, Systematic theology: An introduction to biblical doctrine, InterVarsity Press, Leicester.

Hafemann, S.J., 2014, “"Noah, the preacher of (God's) righteousness”: The argument from Scripture in 2 Peter 2:5 and 9', Catholic Biblical Quarterly 76(2), 306-320.

Harink, D., 2009, 1 \& 2 Peter, BrazosPress, Grand Rapids, MI.

Jordaan, G.J.C., 2014, Die binnewerk van Antieke Grieks: Die semantiek van grammatiese konstruksies. Handleiding vir eksegete en ander studente van Klassieke en Nuwe-Testamentiese Grieks, Potchefstroom Teologiese Publikasies, Potchefstroom.

Jordaan, G.J.C., Janse van Rensburg, F. \& Breed, D.G, 2011, 'Hermeneutiese vertrekpunte vir gereformeerde eksegese', In die Skriflig/In Luce Verbi 45(2/3), 225-258. https://doi.org/10.4102/ids.v45i2/3.14

Käsemann, E., 1964, An apologia for primitive Christian eschatology: Essays on New Testament themes, SCM, London.

Kruger, M.J., 1999, 'The authenticity of 2 Peter', Journal of the Evangelical Theological Society 42(4), 645-671.

Kruger, M.J., 2020, ' 2 Peter 3:2, the apostolate, and a bi-covenantal canon', Journal of the Evangelical Theological Society 63(1), 5-24.

Kümmel, W.G., 1963, Man in the New Testament, Epworth Press, London.

Louw, D.J., 1993, Pastoraat as ontmoeting: Ontwerp vir 'n basisteorie, antropologie, metode en terapie, RGN-Uitgewery, Pretoria.

Louw, J.P. \& Nida, E.A., 1988, Greek-English lexicon of the New Testament based on semantic domains, vol. 1, United Bible Societies, New York, NY.

Moo, D.J., 2011, 2 Peter, Jude, Zondervan, Grand Rapids, MI. (The (NIV Application Commentary).

Nickols, L., 2019, 'Equipping pastors to give pastoral counselling to emotionally wounded children aged between six and twelve', ThD thesis, North-West University, Potchefstroom.

Osmer, R.R., 2008, Practical theology: An introduction, Eerdmans, Grand Rapids, MI.

Paulsen, H., 1992, Der Zweite Petrusbrief und der Judasbrief, Vandenhoeck, Göttingen. (Meyers Kritisch-Exegetischer Kommentar über das Neue Testament).

Pretorius, R., 2017, 'Pastoral care and counselling of families with deaf children: A practical theological model', ThD thesis, North-West University, Potchefstroom.

Reicke, B., 1964, The Epistles of James, Peter, and Jude, Doubleday, New York, NY. (Anchor Bible, vol. 37)

Schreiner, T.R., 2003, 1, 2 Peter, Jude, B\&H Publishing Group, Nashville, TN. (The New American Commentary, vol. 37)

Van Houwelingen, P.H.R., 1988, 'De Tweede Trompet: De authenticiteit van die tweede brief van Petrus', ThD Proefschrift, Theologische Universiteit, Kampen.

Van Houwelingen, P.H.R., 1993, 2 Petrus en Judas. Testament in tweevoud, Kok, Kampen. (Commentaar op het Nieuwe Testament).

Van Houwelingen, P.H.R., 2010, 'The authenticity of 2 Peter: Problems and possible solutions' European Journal of Theology 19(2), 119-129.

Viljoen, F.P., 2012, 'Faithful Christian living in amidst scoffers of the Judgement day: Ethics and ethos in Jude and 2 Peter in identity', in J.G. van der Watt (ed.), Identity ethics, and ethos in the New Testament, pp. 511-533, Walter de Gruyter GmbH \& Co. KG, D-10785, Berlin.

Vinsons, R.B., Wilson, R.F. \& Mills, W.E., 2010, 1 \& 2 Peter, Jude, Smyth \& Helwys, Macon, GA. (Smyth and Helwys Bible Commentary).

Watson, D.F. \& Callan, T.D., 2012, First and Second Peter, Baker Academic, Grand Rapids, MI. (Paideia Commentaries on the New Testament).

Wolters, A.M., 1990, “'Partners of the deity”: A covenantal reading of 2 Peter 1:4' Calvin Theological Journal 25(1), 28-44. 